\title{
Reinier De Graaf (1641-1673) and the Graafian follicle
}

\author{
M. Thiery
}

(C) Springer-Verlag 2009

The name of this seventeenth century Dutch physician remains eponymously linked to the (ripe) ovarian follicle. De Graaf earned his spurs as anatomist and experimental physiologist. However, it was his pioneering work on reproduction that secured him lasting fame within the pantheon of medical history.

Reinier De Graaf was born on 30 July 1641 in Schoonhoven, the son of a Roman Catholic architect [13] (Fig. 1). He started his medical studies at the University of Louvain under Plempius (1601-1671), the 'Primarius' professor of practical medicine with the sonorous first names of Vopiscus Fortunatus. The man 'was born with a caul'. In 1660, Reinier De Graaf continued his studies in Utrecht where Ysbrand van Diemerbroeck (1609-1674) instructed him in anatomy. Three years later, he registered as a student at the University of Leiden. There, he received his inspiration from Franciscus dele Boë Sylvius (16141672), the standard bearer for the iatrochemical school that held the belief that all physiological and pathological processes were the outcome of chemical reactionseffervescence, fermentation, and putrifaction. Reinier De Graaf became so inspired by the latter scientist that he initiated an experimental study on the composition and the

This article was originally published in Tijdschrift voor Geneeskunde. The English version is printed by permission of Prof. Dr. J. Lauweryns, Editor-in-Chief. Life Leuven is acknowledged for the translation.

M. Thiery

Foundation Jan Palfijn and Museum of Medical History,

Ghent, Belgium

M. Thiery $(\bowtie)$

Aan de Bocht 6, 9000 Ghent, Belgium properties of the pancreatic juice and, indeed, succeeded to form an external pancreatic fistula in the dog. $\mathrm{He}$ extensively published the results of this study in Latin [4] and, as early as 1666, also in French. During his years in Leiden, he befriended two brilliant student collaborators who assisted him in his investigative work. Jan Swammerdam (1637-1680) conducted a thorough study of the uterine venous network. Following the publication of De Graaf's book about the female reproductive organs (1672), Jan will accuse his friend of plagiarism and friends turn into enemies [5]. The other member of the historical trio was the Dane Niels Stensen, also known as Steno (1638-1686), whose name is eponymous with the "ductus parotideus"- the parotid duct — and who, subsequently, would also make his name as a geologist. Steno converted to the Roman Catholic faith, was ordained a bishop, and became beatified in 1988 by Pope John Paul II.

Sometime in the spring of 1665, De Graaf left Leiden for a 'peregrinatio academia', a study journey, through France where an interested audience came to listen to his lectures and participated in his demonstrations of the pancreatic fistula. On 23 July 1665, he earned his medical degree of 'medicinae doctor' in Angers, after which he returned to his home country and established himself in Delft at the end of 1666. He became one the most sought-after physicians in that city and further completed his studies on the structure and the functions of male and female sex organs $[6,7]$. De Graaf selected Delft because of its favourable scientific climate, physicians and surgeons were interested in medical investigative work, and he had access there to an anatomy theatre and a well-stocked library. But whilst Leiden was indeed a scientific centre, De Graaf was well aware that an academic career in that city was impossible for him because of his Roman Catholic beliefs. Nonetheless, his years in Delft were happy ones. He found peace and tranquility and 


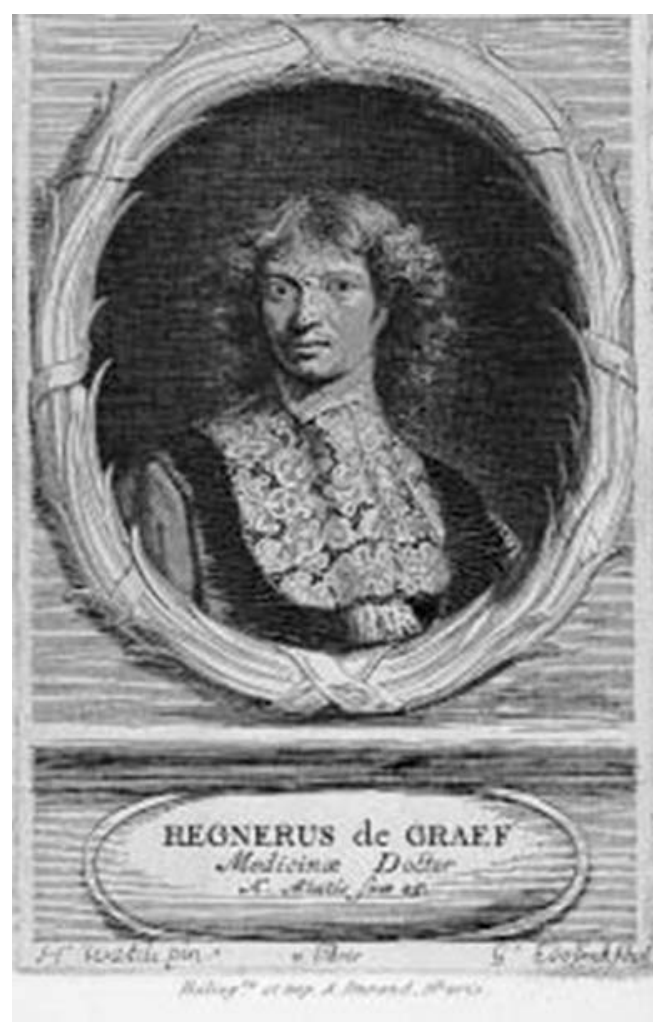

Fig. 1 Doctor Reinier de Graaf at the age of 25. Engraving by G. Edelinck, Paris 1666

married on 13 June 1672. Unfortunately, his married bliss was ended abruptly by his death on 17 August 1673 . His son, who was born after his passing, was christened with his name and also became a physician.

Important in De Graaf's eponym are his theories and findings with respect to the function of the female reproductive organs $[1-3,8]$. Where his predecessors held to the view that the woman, like the man, produced sperm, albeit without any consensus about the function of this hypothetical semen, De Graaf put to rest the age-old theorising and philosophising about the process of generation. Within the 'testes muliebres' (female 'balls'), little 'oval bodies' or capsules, now referred to as follicles, can be found. Following his teacher Johannes Van Horne (1621-1670) in this, De Graaf called these little capsules "eggs" and "female balls" (the latter term "balls" not yet having the vulgar connotation associated with it today. The term 'ball' was used quite naturally by the poet Vondel to denote the globe of the earth) and also "egg nest" or ovary.

The contention that De Graaf might have confused the follicle with the egg cell was contradicted not only by Lindeboom [2]. Also, the embryologist Karl Ernst von Baer, who in 1827 was responsible for the worldwide publication of the discovery of the mammalian egg cell, decried this historical misconception and explained it by the fact that De Graaf used the word in two meanings and sometimes also called the follicles 'eggs'. According to De Graaf, the little capsule grows, and when it is "ripe", it is fertilised in situ, inside the ovary, thanks to a hypothetical "aura seminalis", a seminal breath, which is supposed to be some kind of fluid that passes from the uterus and the tubes into the ovary. The writer was, at the time, unaware of the existence of the spermatozoa, the generative elements of the semen, which the student Johan Ham (1654-1725) will demonstrate to Van Leeuwenhoek (1632-1723). The latter confirmed the discovery and widely published the findings in November 1677, 4 years after the death of De Graaf, in his missive to the London Royal Society. "Subsequently, the egg, now fertilised, is forced out of the "ball" (ovulation) and directed to the uterus via the oviduct (the Fallopian tubes). De Graaf detected the smallest amniotic sacs in the uterine tubes of animals and thus explained the aetiology of the oviduct pregnancy [9]. After having established the connection between the act of copulation and ovulation with rabbits (this rodent being a very suitable medium for the study since in its case ovulation is triggered by coitus), De Graaf suggested that the same process also was applicable in a woman's case. He described the ovarian cycle, the origin and the development of the 'corpus luteum', the yellow body, little globules already observed by his predecessors but without their realising their significance (Fig. 2). He also noted that this yellow body disappeared after pregnancy.

De Graaf surmised correctly when he suggested that the entire beginning of the budding new life lay encompassed

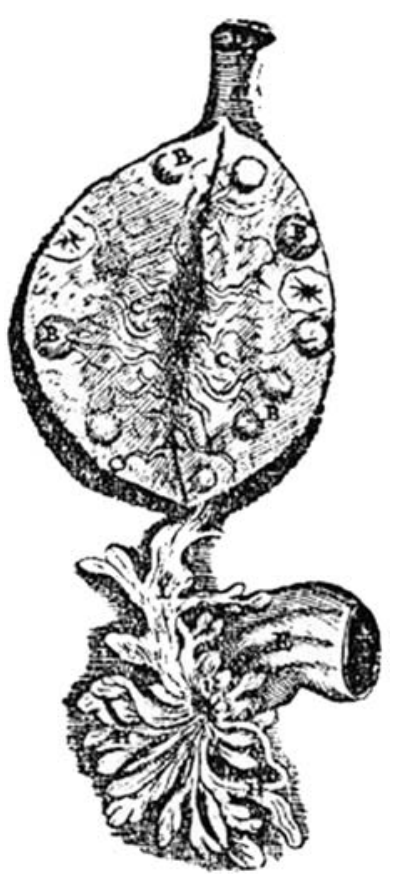

Fig. 2 'De Bal ofte 't Eyer-nest van een Vrouw', representing (the female ball) with an associated part of the trumpet (De Graaf: All of the Works, etc. 1686) 
within the fertilised egg. But De Graaf's belief in 'ovism' was contradicted by Van Leeuwenhoek, who in turn proposed that the embryo is pre-formed in the spermatozoon. However, this difference of opinion between the believers in ovism and the animalculists was of only short duration.

In this brief overview, I have tried to show that De Graaf was the first researcher to have solved the mystery of reproduction. He was the giant that figured as the support pillar to which other scientists had recourse in their studies to advance the knowledge about reproduction and to fill in the details of the reproductive process.

\section{References}

1. Catchpole HR (1940) Regnier De Graaf. Bull Hist Med 8:2611300
2. Lindeboom GA (1973) Reinier de Graaf. Leven en Werken. Publ. Elmar, Delft

3. Houtzager HL (1991) Reinier de Graaf. In: sijn Leven naukeurig Ontleder en gelukkig Geneesheer tot Delft. Mediact BV, Houten

4. De Graaf R (1671) Tractatus Anatomico-medicus de Succi Pancreatici Natura et Usu. ex officina Hackiana, Lugd. Batavorum

5. Houtzager HL (1991) The Collegium Privatum Amstelodamense and the scientific dispute between Reinier de Graaf and Jan Swammerdam. Amstelodanum 78:73-83

6. De Graaf R (1668) De Virorum Organis Generationi Inservientibus, de Clysteribus and De Usu Siphonis in Anatomia. ex officina Hackiana, Lugd Batavorum

7. De Graaf R (1672) De Mulierum Organis Generationi Inservientibus Tractatus Novus, demonstrans tam Homines et Animalia caetera Omnia, quae Vivipara dicuntur, haud minus quam Ovipara ab Ovo Originem Ducere. ex officina Hackiana, Lugd Batavorum

8. Thiery M, Houtzager HL (1997) Der Vrouwen Vrouwlijcheit. Erasmus, Rotterdam

9. Houtzager HL (1996) Reinier De Graff en zijn visie op het ontstaan van een extra-uteriene graviditeit. J Med 52:953-956 